\title{
DE
}

DE GRUYTER

OPEN

DOI: $10.1515 /$ jolace-2017-0003

\section{Reading input flooding versus listening input flooding: Can they boost speaking skill?}

\author{
Mojgan Rashtchi \& Leila Mohammad Yousefi \\ Islamic Azad University, North Tehran Branch, Iran \\ mojgan.rashtchi@gmail.com
}

\begin{abstract}
The present study compared the effects of reading input flooding and listening input flooding techniques on the accuracy and complexity of Iranian EFL learners' speaking skill. Participants were 66 homogeneous intermediate EFL learners who were randomly divided into three groups of 22: Reading input flooding group, listening input flooding group, and control group. The reading flooded input group was exposed to the numerous examples of the target structures through reading. In the same phase, the listening group was given relatively the same task, through listening. The participants' monologues in the posttest were separately recorded, and later transcribed and coded in terms of accuracy and complexity through Bygate's (2001) standard coding system. The results of ANCOVA indicated the outperformance of reading input flooding group. The study also supported the trade-off effects (Skehan, 1998, 2009) between accuracy and complexity.
\end{abstract}

Key words: accuracy, complexity, listening input flooding, reading input flooding, speaking skill

\section{Introduction}

Input enhancement (and input flooding as one of its versions) is Sharwood Smith's (1993) expression for referring to any pedagogical technique that teachers use to make specific features in the input more salient because noticing the input facilitates its learning (Schmidt, 1990). However, the findings in the domain of input enhancement are controversial. While some studies emphasize the usefulness of input enhancement and input flooding techniques (Ellis, 2003; Izumi, 2002; Jourdenais, Ota, Stauffer, Boyson, \& Daughty, 1995; Lee, 2007; Rashtchi \& Gharanli, 2010; Shook, 1999; Simard, 2009) others minimize their efficacy (Alanen, 1995; Leow, Egi, Nuevo, \& Tsai, 2003; Overstreet, 1998; Radwan, 2005; Wong, 2003).

Input flooding is an implicit technique of focusing on form in the dichotomy of implicit and explicit activities that attempt to attract students' attention. Spada 
(1997) stated that form-focused instructions are pedagogical efforts used to call learners' attention to the target features either implicitly or explicitly. In the process of input flooding, learners' exposure to saturated input filled with substantial examples in oral and written forms facilitates their acquisition. As Gass (1997) pointed out, the frequency of exposure to target forms could significantly affect their learning. This kind of input enhancement is ideal for meaning-based classrooms that focus on meaningful interaction and encourage incidental acquisition. Input flooding is a technique that does not require the teacher to stop an activity to point something out but can leave language learners on their own to make connections between form and meaning. Wong (2005) argued that input flood could be too implicit since the learners might not be able to notice the new target forms. Several studies on input flooding have documented its role in the learning of different features of languages. For example, Lee (2002) showed the efficacy of input flooding in the acquisition of Spanish future tense, Trahey and White (1993) indicated its effectiveness in learning the meanings and placements of English adverbs while White (2015) demonstrated its positive role in learning Spanish accusative clitics. Likewise, Rikhtegar and Gholami (2015) indicated that input flooding could enhance the acquisition of the English simple past tense. Tabatabaei and Yakhabi (2009) found that although learners' language production could enhance the accurate use of grammar, input flooding has a decisive role in speech complexity. However, Reinder and Ellis (2009) found no positive effect of input enhancement on the acquisition of English negative adverbs suggesting the necessity of explicit instruction for some language features. Hernandez (2008) also showed that explicit instruction combined with input flooding was more successful than input flooding alone in improving students' use of discourse markers.

Reading and listening are the sources of language input for EFL/ESL learners and play crucial roles in promoting their competence. Reading input flooding can facilitate the acquisition of target language features by increasing their frequency of occurrence. It is assumed that the more a certain language structure is repeated in the input, the higher will be the chance of paying attention to it (Wagner-Gough \& Hatch, 1975). On the other hand, by listening input flooding, L2 learners are drenched with a large quantity of input before being encouraged to respond orally. Reading and listening can provide language learners with saturated input that can be converted into intake if the required mental processes are available (Brown, 2001) and if the amount of the input is sufficient (Krashen, 1994).

Accuracy, complexity, and fluency are three components of the speaking skill that can affect the process of communication. Accuracy, as Bygate (1999) put forward, includes vocabulary, idiomatic phrases, grammatical morphemes, and pronunciation patterns that appear to be the formal features of a language. 
Complexity is the utilization of interlanguage structures that are "cutting edge, elaborate, and structured" (Ellis, 2003, p. 113) while fluency refers to the smoothness with which sentences are uttered. Skehan (1998) believed that there is a trade-off between complexity and accuracy; that is, attaching more importance to one component could result in giving less importance to another. Skehan (2009) predicted that the limited capacity of mental resources and working memory could be the source of the competitive relationship among complexity, accuracy, and fluency. From a psycholinguistic perspective, simultaneous attention to all components of language at the highest level is not possible for a learner, and thus focusing on one constituent at a time is important while speaking (Vercellotti, 2012).

The primary purpose of the present study was to compare the effects of reading and listening input flooding techniques on the accuracy and complexity of the speaking ability of Iranian EFL learners. In addition, the study intended to examine whether there was any relationship between accuracy and complexity features of speaking skill. Thus, the researchers formulated the following research questions:

RQ1: Do reading input flooding and listening input flooding techniques similarly affect the speaking accuracy of Iranian EFL learners?

RQ2: Do reading input flooding and listening input flooding techniques similarly affect the speaking complexity of Iranian EFL learners?

RQ3: What is the relationship between accuracy and complexity dimensions of Iranian EFL Learners' speaking skill?

\section{Method}

\section{Participants}

Sixty-six men and women ELT major college students at BA level participated in this study. Their proficiency level was controlled through the listening and speaking sections of Preliminary English Test (PET). They were randomly assigned to three groups: the reading input flooding group (Group $\mathrm{A}, \mathrm{n}=22$ ), the listening input flooding group (Group $\mathrm{B}$, $\mathrm{n}=22$ ), and the control group (Group $\mathrm{C}, \mathrm{n}=22$ ). The age of the participants ranged from 19 to 28.

\section{Instrumentation}

The first instrument was a listening and speaking test adopted from a sample of PET Practice Tests (Appendix A), used to select 66 participants. The test originally consists of 35 reading items, 25 writing items, 25 listening items, and a twelve-minute test of speaking. Since the focus of this study was on oral speech assessment, the reading and writing sections were discarded. The reliability of the listening and speaking sections were computed through KR-21 formula ( $\mathrm{r}=.78)$. 
Monologues as another data-gathering tool were used for collecting the data related to the participants' speaking ability. The monologues helped the researchers to measure the participants' speaking ability before and after the treatment. Their topics (e.g., the most beautiful place in their country, a memorable day in their life) were selected from American English File2 (Bowden, Latham King, and Hudson, 2008). The monologues were recorded, transcribed, and scored through standard coding scheme to measure the participants' oral speech. The coding process was done in terms of grammatical accuracy and syntactic complexity based on Bygate's (2001) standard coding system. In this system, complexity is measured in terms of the number of words per T-unit, where T-unit is defined as "finite clause together with any subordinate clauses dependent on it" (Bygate, 2001, p. 35). Accuracy was measured by calculating the incidence of errors per T-unit; that is, the higher the number, the less accurate the language was (Bygate, 2001).

\section{Procedure}

Pretest

Although the listening and speaking sections of PET were used for the sample selection, the speaking ability of the participants was assessed for a second time to ensure their homogeneity. Each participant performed a ten-minute monologue the results of which showed no significant difference in his or her speech accuracy and complexity. Then the three intact classes were randomly assigned to three groups of the study.

\section{Treatment}

The groups received the same instruction and the only difference was that Group A received the input through reading while Group B received it through listening. The treatment took two months, two sessions in a week and each session about 60 minutes. The classroom activities in both classes were selected from American English File2 (Bowden et al., 2008). Each session, a section of reading and listening parts were covered. The experimental groups practiced similar topics and structures to enable the researchers to conclude that under relatively identical conditions (e.g., the same age range, level of speaking skill, L1, allotted time, and topic) any changes in the groups could be due to the treatment.

During the input flooding sessions, the learners were bombarded by an "artificially increased" number of the target forms (Francis, 2003). In this study, Simple Present, Simple Past, Simple Future, Be going to, Present Perfect, Present Continuous, Past Perfect, and Past Continuous were taught in flooded input mode. For instance, in Group A, the teacher explained Be going to and asked the students to provide examples first in structural phrases such as going to read, going to swim, going to walk, and then in complete sentences. Afterwards, the teacher divided the 
class into groups of three and asked them to engage in discussion that contained sentences made by "be going to". As the next step, the teacher asked the students to take turns and read the reading passage aloud. The reading phase was followed by finding the target structures and underlining them in the passage. In addition, the participants wrote sentences with the target structures and read them out for the class. As the final step, the students talked about a topic they were interested in while using be going to.

Group B was given similar tasks, but through listening. For instance, like Group A, the teacher explained be going to and asked students to give examples first in structural phrases such as going to read and going to swim, and then in complete sentences. Similar to the reading group, the teacher divided the class into groups of three and asked each group to lead discussions while using be going to. Then the students listened to a passage that included be going to and summarized it. The passage was played twice; first, they listened and then took notes. The topics and structures were relatively similar to the topics and structures given to the group A. Likewise, as the speaking task, the students were asked to prepare an oral presentation while using be going to structure.

The control group (Group C) was not engaged in activities that could be associated with input flooding. They merely attended their regular classes. For instance, during a session, the teacher explained, be going to and wrote some examples on the board which the students read them aloud. Subsequently, one of the learners read the passage expressively to provide the class with "going to" structure. Then the learners had 10 minutes to read the text individually and summarize it. At the final stage, similar to the other two groups, the participants prepared an oral presentation on a topic of interest using be going to. It is worth mentioning that the reading passages were identical with the ones in groups A and B.

\section{Posttest}

After the treatment, the participants performed a ten-minute monologue about an unrehearsed topic selected from their course book. Like the pretest, the researchers recorded and transcribed the oral performances and used Bygate's (2001) standard coding system to code the transcriptions regarding accuracy and complexity. In this coding system, accuracy is counted by the number of errors per T-unit and complexity by number of words per T-unit. The students with fewer grammatical errors in each T-unit received higher scores in accuracy and those with longer sentences (more words per T-unit) received higher scores in complexity. 


\section{Results}

As shown in Table 1, the students in reading group $(M=43.32, S D=3.53)$ did not perform far better than the listening group $(M=41.68, S D=3.34)$ and the control group $(M=42.18, S D=3.08)$ on Reading and Listening Test.

Table1: Descriptive Statistics for Reading and Listening Proficiency, Three Groups

\begin{tabular}{llllll}
\hline \multicolumn{1}{c}{ Variable } & Time & Groups & N & Mean & SD \\
\hline Reading and & & Reading & 22 & 43.32 & 3.537 \\
Listening & \multirow{2}{*}{ Proficiency } & Listening & 22 & 41.68 & 3.344 \\
Proficiency & & Control & 22 & 42.18 & 3.080 \\
\hline
\end{tabular}

The results of the one-way ANOVA before the treatment (Table 2) showed no statistically significant differences among the groups $F(2,63)=1.39, p>.05$; thus, it could be concluded that the three intact groups belonged to the same population.

Table 2. ANOVA for Comparing the Groups' Reading and Listening Proficiency

$\begin{array}{lllll}\begin{array}{c}\text { Sum of } \\ \text { Squares }\end{array} \text { df } & \text { Mean Square }\end{array}$

\begin{tabular}{llllll}
\hline Between Groups & 30.939 & 2 & 15.470 & 1.399 & .254 \\
Within Groups & 696.818 & 63 & 11.061 & & \\
Total & 727.758 & 65 & & & \\
\hline
\end{tabular}

Table 3 shows the descriptive statistics of grammatical accuracy scores on the pretest and posttest. As signified, speech accuracy means were not very different among the three groups on the pretest; however, on the posttest the largest mean is for the reading group $(M=.71)$ followed by the listening $(M=.64)$, and the control group $(M=.54)$. To control the effect of the pretesting procedures and interaction effect of pretesting (Best \& Khan, 2006) that could threaten both the internal and external validities of the study, a one-way between groups analysis of covariance (ANCOVA) was conducted to answer the first research question. The independent variable were the groups (Group A, Group B, and Control), and the dependent variable was the accuracy scores on the posttest. Participants' scores on the pretest were used as the covariate. It is worth mentioning that three assumptions of normality, homogeneity of variances, and homogeneity of regression slopes examined before running the one-way ANCOVA legitimized its use. 
Table 3. Descriptive Statistics, Speech Accuracy Scores on the Pretest and Posttest

\begin{tabular}{clllll}
\hline Source & Time & Groups & N & Mean & SD \\
\hline \multirow{5}{*}{ Accuracy } & \multirow{4}{*}{ Pretest } & Reading & 22 & .569 & .162 \\
\cline { 3 - 6 } & & Listening & 22 & .570 & .134 \\
& \multirow{4}{*}{ Posttest } & Control & 22 & .528 & .169 \\
\cline { 3 - 6 } & & Reading & 22 & .710 & .150 \\
& & Listening & 22 & .642 & .153 \\
\cline { 3 - 6 } & & Control & 22 & .541 & .161 \\
\hline
\end{tabular}

As Table 4 indicates, after adjusting for the role of the pretest of accuracy, there was a statistically significant difference among the three groups on the posttest of accuracy, $F(2,62)=11.08, p<.05$. That is, there was a significant association between the covariate (pre-accuracy) and the dependent variable (post-accuracy) while adjusting for the independent variable (group). In addition, eta squared $\left(\eta^{2}=\right.$ .65 ) implied that $65 \%$ of the overall variance was due to the independent variable.

Table 4. One-way ANCOVA for Comparing the Groups on Speech Accuracy Scores

\begin{tabular}{lllllll}
\hline Source & $\begin{array}{l}\text { Type III } \\
\text { Sum of } \\
\text { Squares }\end{array}$ & $D f$ & $\begin{array}{l}\text { Mean } \\
\text { Square }\end{array}$ & $F$ & Sig. & $\begin{array}{l}\text { Partial Eta } \\
\text { Squared }\end{array}$ \\
\hline Corrected Model & $1.305^{\mathrm{a}}$ & 3 & .435 & 50.231 & .000 & .708 \\
Intercept & .156 & 1 & .156 & 17.977 & .000 & .225 \\
Accuracy Pre-test & 1.000 & 1 & 1.000 & 115.528 & .000 & .651 \\
Group & .192 & 2 & .096 & 11.085 & .000 & .263 \\
Error & .537 & 62 & .009 & & & \\
Total & 28.264 & 66 & & & & \\
Corrected Total & 1.841 & 65 & & & &
\end{tabular}

a. R Squared $=.708$ (Adjusted R Squared $=.694$ )

Post hoc pairwise comparison (Table 5) indicated that there was a statistically significant difference in speech accuracy scores between the reading group $(M=$ $.71, S D=.15)$ and the control group $(M=.54, S D=.16)$. In addition, there was a statistically significant difference in accuracy scores between the reading and 
listening groups. Thus, it could be concluded that reading group $(M=.71)$ outperformed the listening group $(M=.64)$.

Table 5. Post Hoc Pairwise Comparison of the Groups' Speech Accuracy Scores

\begin{tabular}{|c|c|c|c|c|c|c|}
\hline \multirow{2}{*}{ (I) Group } & \multirow{2}{*}{ (J) Group } & \multirow{2}{*}{$\begin{array}{l}\text { Mean } \\
\text { Difference } \\
(\mathrm{I}-\mathrm{J})\end{array}$} & \multirow{2}{*}{$\begin{array}{l}\text { Std. } \\
\text { Error }\end{array}$} & \multirow{2}{*}{ Sig. } & \multicolumn{2}{|c|}{$\begin{array}{l}\text { 95\% Confidence } \\
\text { Interval for Difference }\end{array}$} \\
\hline & & & & & $\begin{array}{l}\text { Lower } \\
\text { Bound }\end{array}$ & $\begin{array}{l}\text { Lower } \\
\text { Bound }\end{array}$ \\
\hline \multirow{2}{*}{ Control } & Reading & $-.133^{*}$ & .028 & .000 & -.189 & -.076 \\
\hline & Listening & $-.064^{*}$ & .028 & .028 & -.120 & -.007 \\
\hline Reading & Listening & $.069^{*}$ & .028 & .016 & .013 & .125 \\
\hline
\end{tabular}

In order to answer the second research question, again a one-way ANCOVA was run. As shown in Table 6, the mean scores of the speech complexity are close to each other on the pretest, whereas on the posttest the largest mean belongs to the reading group followed by the listening group, and the control group. In order to ensure that the assumption of normality was not violated, the homogeneity of variances and the homogeneity of regression slopes were conducted.

Table 6. Descriptive Statistics for Speech Complexity Scores on the Pretest and Posttest

\begin{tabular}{llllll}
\hline \multirow{4}{*}{ Time } & Groups & N & Mean & SD \\
& \multirow{4}{*}{ Pretest } & Reading & 22 & 52.510 & 12.525 \\
& & Listening & 22 & 50.169 & 9.830 \\
& Control & 22 & 51.478 & 11.900 \\
\cline { 2 - 5 } Complexity & & Reading & 22 & 68.403 & 11.291 \\
& \multirow{2}{*}{ Posttest } & Listening & 22 & 59.813 & 11.569 \\
& & Control & 22 & 51.666 & 12.361 \\
\hline
\end{tabular}

As the results of one-way ANCOVA (Table 7) signifies, there was a statistically significant difference among the three groups on the posttest of the speech complexity, $F_{(2,62)}=24.74, p<.05, \eta 2=.44$. The effect size $(\eta 2)$ indicates a large effect size (Cohen, 1988: 284-7) and shows that input flooding by itself accounted for almost $44 \%$ of the overall variance. 
Table 7: One-way ANCOVA for Comparing the Groups on Speech Complexity Scores

\begin{tabular}{lllllll}
\hline Source & $\begin{array}{c}\text { Type III Sum } \\
\text { of Squares }\end{array}$ & $d f$ & $\begin{array}{l}\text { Mean } \\
\text { Square }\end{array}$ & $F$ & Sig. & $\begin{array}{l}\text { Partial Eta } \\
\text { Squared }\end{array}$ \\
\hline Corrected Model & $8261.426^{\mathrm{a}}$ & 3 & 2753.809 & 48.537 & .000 & .701 \\
Intercept & 1124.714 & 1 & 1124.714 & 19.823 & .000 & .242 \\
Complexity & 5179.543 & 1 & 5179.543 & 91.291 & .000 & .596 \\
Pre-test & 2807.438 & 2 & 1403.719 & 24.741 & .000 & .444 \\
Group & 3517.685 & 62 & 56.737 & & & \\
Error & 249072.011 & 66 & & & & \\
Total & 11779.112 & 65 & & & & \\
Corrected Total & 65 & & & &
\end{tabular}

a. R Squared $=.701$ (Adjusted R Squared $=.687$ )

Post hoc pairwise comparison (Table 8) illustrated that that there was a statistically significant difference $(p<.05)$ between the reading group $(M=68.40$, $S D=11.29)$ and the control group $(M=51.66, S D=12.36)$ regarding speech complexity. Also, there is a statistically significant difference $(p<.05)$ between the listening group $(M=59.81, S D=11.56)$ and the control group $(M=51.66, S D=$ 12.36). It could be inferred that both reading and listening input flooding could improve the participants' oral complexity. Further, as Table 8 shows, there is a statistically significant difference between the reading and listening groups $(p<$ .05 ) in terms of complexity scores. Put differently, the students in reading group $(M=68.40)$ outperformed the listening group $(M=59.81)$ regarding oral complexity.

Table 8. Post Hoc Pairwise Comparison of the Groups' Speech Complexity Scores

\begin{tabular}{lllllll}
\hline & & Mean & & \multicolumn{3}{l}{$\begin{array}{l}\text { 95\% Confidence Interval } \\
\text { for Difference }\end{array}$} \\
\cline { 4 - 6 } Group & (J) Group & $\begin{array}{l}\text { Difference } \\
\text { (I-J) }\end{array}$ & $\begin{array}{l}\text { Std. } \\
\text { Error }\end{array}$ & Sig. & $\begin{array}{l}\text { Lower } \\
\text { Bound }\end{array}$ & Lower Bound \\
\hline \multirow{2}{*}{ Control } & Reading & $-15.921^{*}$ & 2.273 & .000 & -20.464 & -11.378 \\
Reading & Listening & $-9.181^{*}$ & 2.274 & .000 & -13.726 & -4.636 \\
\hline
\end{tabular}


The third research question aimed to explore whether there is a relationship between the accuracy and complexity dimensions of Iranian EFL learners' speaking skill. Pearson product moment correlation coefficient was performed between the scores obtained from accuracy and complexity features. As Table 8 shows, there is a significant negative correlation between the set of accuracy and complexity scores within the reading group $(r=-0.71)$, listening group $(r=-0.66)$, and control group $(r=-0.61)$. Therefore, it was found that there exists a trade-off effect between accuracy and complexity dimensions of the speaking skill.

Table 9. Correlation of Accuracy and Complexity Scores within Groups

\begin{tabular}{llll}
\hline & Complexity Scores & $\begin{array}{l}\text { Sig. (2- } \\
\text { tailed) }\end{array}$ & $\mathrm{N}$ \\
\hline $\begin{array}{l}\text { Accuracy Scores } \\
\text { (Reading) }\end{array}$ & $-0.714^{* *}$ & 0.000 & 22 \\
$\begin{array}{l}\text { Accuracy Scores } \\
\text { (Listening) }\end{array}$ & $-0.667^{* *}$ & 0.001 & 22 \\
$\begin{array}{l}\text { Accuracy Scores } \\
\text { (Control) }\end{array}$ & $-0.615^{* *}$ & 0.002 & 22 \\
$* *$ Correlation is significant at the 0.01 level (2-tailed).
\end{tabular}

\section{Discussion}

The results of the present study showed the positive impact of input flooding on developing accuracy in the speaking skill. It could be stated that noticing occurs when target features are provided with a high frequency (Gass, 1997) resulting in meaning-focused L2 instruction (Wong, 2005). Frequent use of language features in the classroom can create comprehensible input and thus facilitate learning. The findings of this study are in favor of implicit flood of language features in the classroom instruction (Reinders \& Ellis, 2009; VanPatten, Williams, \& Rott, 2004).

Regarding the second research question, the statistical analysis of the posttest showed a significant difference between the speaking skill of the reading and listening input flooding groups and the control group in terms of complexity. This finding is in line with Tabatabaei and Yakhabi (2009) who showed that comprehensible input and output positively affect the accuracy and complexity of L2 speaking. However, as the literature signifies, research on the effect of reading and listening input flooding concerning the complexity of the speaking ability is limited and further studies are necessary to clarify the issue.

The third research question investigated whether there was any relationship between accuracy and complexity dimensions of Iranian EFL learners' speaking ability. The result of Pearson's $r$ showed that there was a negative correlation between the set of accuracy and complexity scores within the reading, listening, 
and control groups. The analysis of each participant's score showed that those who devoted their attention to complexity in speaking diverted their attention from formal linguistic features; that is, the higher the accuracy, the lower was the complexity. The negative correlation could be due to the restrictions in attentional resources of human beings (Skehan \& Foster, 2001; D'Ely, 2006). Thus, giving importance to one component might result in redirection of attention from other constituents. Therefore, a trade-off could also be expected between complexity and accuracy since learners' cognitive capacity may not allow simultaneous attention to them. The present study finds support from Ferrari (2012), Kim and Tracy-Ventura (2013), and Evelyn and Marije (2014) who found that decreasing syntactic complexity of tasks resulted in increasing accuracy and vice-versa.

\section{Conclusions}

The results of this study imply that input flooding provides an opportunity for Iranian EFL learners at the intermediate level to extend their capabilities for gaining knowledge about the English language features. Using flooded input could be a way to draw on EFL learners' prior knowledge of the content and stimulate more active participation. The result of this study could be of interest to EFL teachers who seek new techniques to improve students' speaking skill. Exposure to saturated input as a relatively new technique for boosting speaking ability can bring about considerable progress. It could be assumed that increasing frequency of occurrence of a feature in the input makes it more noticeable, draws learners' attention to the intended form, and facilitates the acquisition of target structures.

Presumably, salient implicit input converts to intake, shifts to long-term memory, and becomes available in future interactions. Input flooding leads to better comprehension and improves the accuracy and complexity of speech production. The researchers of the present study suggest the integration of listening and reading input flood in EFL classes to provide exposure to both of the skills. However, this study was a small-scale study with participants who were selected from a language school in an EFL setting. Thus, the findings should be generalized to other settings and participants with caution. Further studies can elucidate whether the findings are broadly applicable.

\section{References}

Alanen, R. (1995). Input enhancement and rule presentation in second language acquisition.

In R. Schmidt (Ed.), Attention and awareness in foreign language acquisition (pp. 259-302). Honolulu, HI: University of Hawaii.

Best, J., \& Kahn, J.V. (2006). Research in education (tenth ed.). Boston, MA: Pearson. 
Bowden, C., Latham King, C. \& Hudson, J. (2008). American English files. Cambridge: Cambridge University Press.

Bygate, M. (1999). Task as context for the framing, reframing, and unframing of language. System, 27, 33-48. DOI: http://dx.doi.org/10.1016/S0346251X(98)00048-7

Bygate, M. (2001). Effects of task repetition on the structure and control of oral language. In M. Bygate, P. Skehan, \& M. Swain (Eds.). Researching pedagogic tasks: Second language learning and testing (pp. 37-53). London: Longman.

Brown, H. D. (2001). Teaching by principles: An interactive approach to language pedagogy ( $2^{\text {nd }}$ ed.). New York, NY: Longman.

Cohen, J. W. (1988). Statistical power analysis for the behavioral sciences (2nded.). Hillsdale, NJ: Lawrence Erlbaum.

D'Ely, R. (2006). A focus on learners' metacognitive process: The importance of the strategic planning, repetition, strategic planning plus repetition and strategic planning for repetition on L2 oral performance (Unpublished doctoral dissertation). Santa Catarina University, Brazil.

Ellis, R. (2003). Task-based language learning and teaching. Oxford: Oxford University Press.

Evelyn, S., \& Marije, M. (2014). An exploratory study into trade-off effects on complexity, accuracy, and fluency on young learners' oral task repetition. TESL Canada Journal, 30(4), 23-48.

Ferrari, S. (2012).A longitudinal study of complexity, accuracy, and fluency variation in second language development. In A. Housen, F. Kuiken, \& I. Vedder (Eds.), Dimension ofL2 performance and proficiency: Complexity, accuracy, and fluency in SLA (pp. 227-297). Philadelphia: John Benjamins.

Francis, S. (2003). Input flooding and the acquisition of the Spanish verbs ser and estar for beginning level adult learners (Unpublished doctoral dissertation), Purdue University, Lafayette, Indiana.

Gass, S. (1997). Input, interaction, and the second language learner. Mahwah, NJ: Lawrence Erlbaum.

Hernandez, T.A. (2008). The effect of explicit instruction and input flood on students' use of discourse markers on a simulated oral proficiency interview. Hispania, 91, 665-75.

Izumi, S. (2002). Output, and input enhancement, and the noticing hypothesis: An experimental study of ESL relativization. Studies in Second Language Acquisition, 24,541-577. DOI: http://doi.org/10.1017/S0272263102004023

Jourdenais, R., Ota, M., Stauffer, S., Boyson, B., \& Daughty, C.J. (1995). Does textual enhancement promote noticing? In R. Schmidt (Ed.). Attention and awareness in foreign language learning (pp, 183-216). Honolulu, Hawai'i: University of Hawai'i Press. 
Kim, Y., \& Tracy-Ventura, N. (2013). The role of task repetition in L2 performance development: What needs to be repeated during task-based instruction? System, 44(3), 829-840. DOI: http://dx.doi.org/10.1016/j.system.2013.08.005 Krashen, S. (1994).The pleasure hypothesis. In J. Alatis (Ed.), Georgetown University Roundtable on Language and Linguistics (pp. 299-322). Washington: Georgetown University Press.

Lee, S.K. (2007). Effects of textual enhancement and topic formality on Korean EFL students' reading comprehension and learning of passive form. Language Learning, 57, 87-118. DOI: 10.1111/j.1467-9922.2007.00400.x

Lee, J.F. (2002). The incidental acquisition of Spanish future morphology through reading in a second language. Studies in Second Language Acquisition, 24(1), 55- 80. Leow, R.P., Egi, T., Nuevo, A.M., \&Tsai, Y.-C. (2003).The roles of textual enhancement and type of linguistic item in adult L2 learners' comprehension and intake. Applied Language Learning, 13, 1-16.

Overstreet, M. (1998). Textual enhancement and content familiarity: The focus of learner attention. Spanish Applied Linguistics, 2, 229-259.

Radwan, A. (2005). The effectiveness of explicit attention to form in language learning. System, 33, 69-87. http://dx.doi.org/10.1016/j.system.2004.06.007

Rashtchi, M., \& Gharanli, L. (2010). Noticing through input enhancement: Does it affect learning of the conditionals? Journal of Language and Translation, 1(1), 19-27.

Reinders, H., \& Ellis, R. (2009). The effects of two types of input to intake and the acquisition of implicit and explicit knowledge. In R. Ellis, S. Loewen, C. Elder, R. Erlam, J. Phlip, \& H. Reinders (Eds.), Implicit and explicit knowledge in second language learning, testing and teaching (pp.281-302). Bristol: Multilingual Matters.

Rikhtegar, O., \&Gholami, J. (2015). The effect of pre-verses post-presentation input flooding via reading on the young EFL learners' acquisition of simple past tense. English Language Teaching, 8(3), 80-88. DOI:10.5539/elt.v8n3p80

Schmidt, R. W. (1990). The role of consciousness in second language learning. Applied Linguistics, 11(2), 129-158.

Sharwood Smith, M. (1993). Input enhancement in structured SLA: Theoretical Bases. Studies in Second Language Acquisition, 15, 154-179.

Shook, D.J. (1999). What foreign language recalls reveal about the input-to-intake phenomenon? Applied Language Learning, 10, 39-76.

Simard, D. (2009). Differential effects of textual enhancement formats on intake. System, 37(1), 124-135. http://dx.doi.org/10.1016/j.system.2008.06.005

Skehan, P. (1998). A cognitive approach to language learning. Oxford: Oxford University Press. 
Skehan, P. (2009). Modelling second language performance: Integrating complexity, accuracy, fluency, and lexis. Applied linguistics, 30(4), 510-532. DOI: https://doi.org/10.1093/applin/amp047

Skehan, P., \& Foster, P. (2001). Cognition and tasks. In P. Robinson (Ed.), Cognition and second language instruction (pp. 183-207). Cambridge: Cambridge University Press.

Spada, N. (1997). Form-focused instruction and second language acquisition: Review of classroom and laboratory research. Language Teaching, 30, 73-87. DOI: https://doi.org/10.1017/S0261444800012799

Tabatabaei, 0.,\& Yakhabi, M. (2009). The effect of comprehensible input and comprehensible output on the accuracy and complexity of Iranian EFL learner's oral speech. The Journal of Applied Linguistics, 2, 218-248.

Trahey, M., \& White, L. (1993). Positive evidence and preemption in the second language classroom. Studies in Second Language Acquisition, 15, 181-204. DOI: https://doi.org/10.1017/S0272263100011955

VanPatten, B., Williams, J., \& Rott, S. (2004). Form-meaning connections in second language acquisition. In B. VanPatten, J. Williams, S. Rott, \& M. Overstreet (Eds.), Form-meaning connections in second language acquisition (pp. 1-26). Mahwah, NJ: Lawrence Erlbaum.

Vercelloti, M. (2012). Complexity, accuracy, and fluency as properties of language performance: The development of the multiple subsystems over time and in relation to each other. (Unpublished doctoral dissertation). University of Pittsburgh, NY.

Wagner-Gough, J., \& Hatch, E. (1975). The importance of input in second language acquisition studies. Language Learning 25 (2), 297-308. DOI: 10.1111/j.14671770.1975.tb00248.x

White, P. (2015). The effects of input-based instructions on the acquisition of Spanish accusative clitics. Hispania, 98(2), 264-284.

Wong, W. (2003). Textual enhancement and simplified input: Effects on L2 comprehension and acquisition of non-meaningful grammatical form. Applied Language Learning, 13(2), 109-132.

Wong, W. (2005). Input enhancement: From theory and research to the classroom. New York, NY: McGraw-Hill.

\section{Contact}

Mojgan Rashtchi , PhD, Associate Professor of Applied Linguistics TEFL Department, Islamic Azad University, North Tehran Branch Babaii High way, Hakimiyeh

Iran

E-mail: mojgan.rashtchi@gmail.com 


\section{Appendix A}

\section{Speaking and Listening Sections of PET}

Test 4 Listening Part 1

4 How did the woman hear from James?

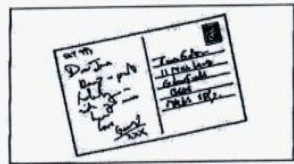

A $\square$

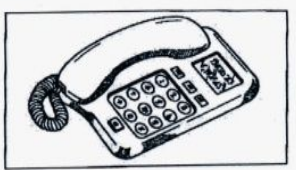

B $\square$

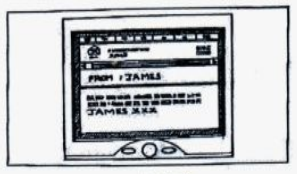

c $\square^{-}$

5 What is the date of the marathon?

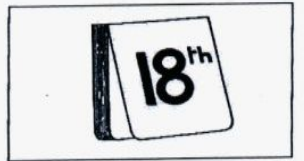

A $\square$

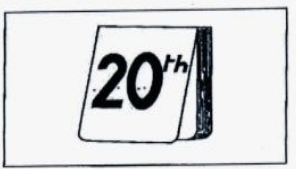

в $\square$

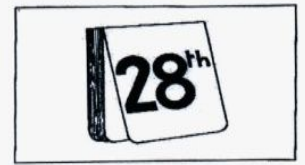

$c \square$

6 What's the weather going to be like tomorrow?

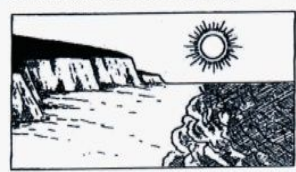

A $\square$

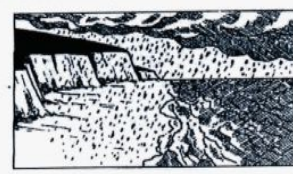

B $\square$

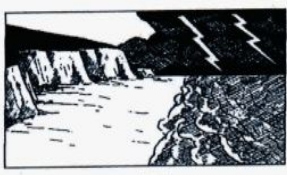

$c \square$

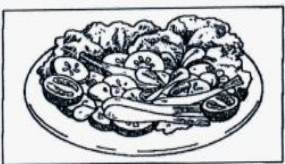

c $\square$

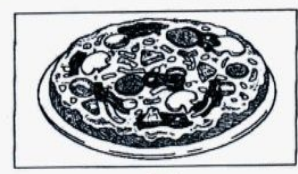

B $\square$

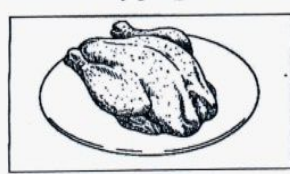

A $\square$ 
Paper 2 Listening (about 30 minutes) Part 1.

\section{Questions 1-7}

There are seven questions in this part.

For each question there are three pictures and a short recording.

Choose the correct picture and put a tick ( $M$ ) in the box below it.

Example: How does the woman travel to work?

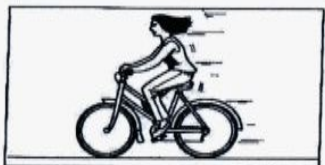

A $\square$

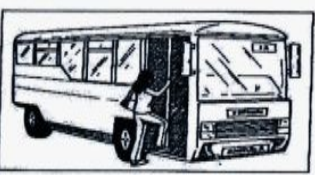

B $\square$
Tip

Think about the question and listen to the whole reconding for each one before you choose your answer. The speakers may talk about more than one of the pictures but only one is the right anewer for the question.

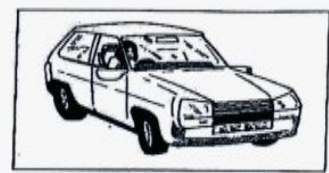

$c \square$
1 What is the woman going to read on the plane?

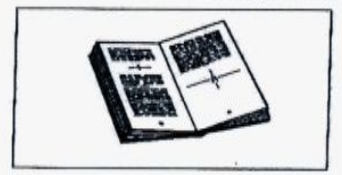

A $\square$

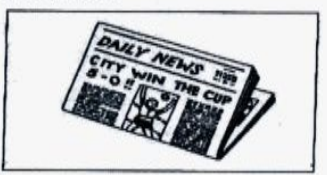

B $\square$

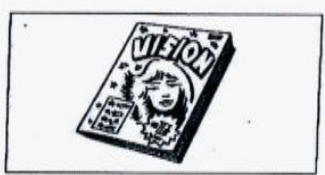

$c \square$
2 What will Mr Brown find at the desk?

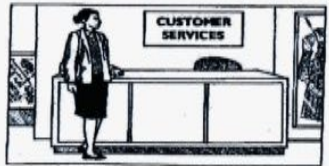

A $\square$

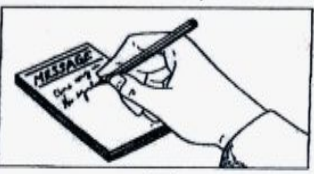

B $\square$

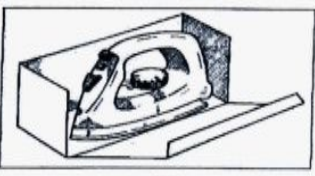

$c \square$
3 Where is the hotel?

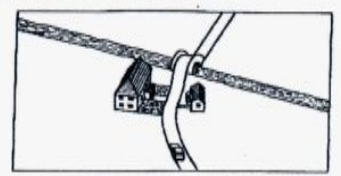

A $\square$

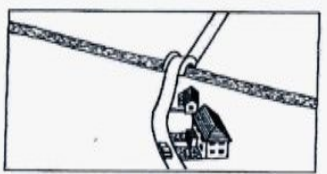

B

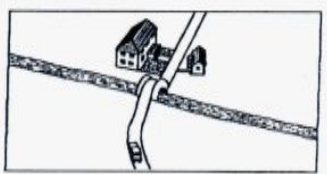

$c \square$ 


\section{Part 2}

\section{Questions 8-13}

You will hear someone talking about summer activities. For each question, put a tick $(W)$ in the correct box.
Tip

Don't choose an answer just because you hear a word from it on the recording.
8 What does the presenter say about the Triple Theatre Company?

9 Open air concerts are held

10 One performance of Twelfth Night is cancelled because

11 The concert at the weekend water festival will take place

12 What is true about people taking part in the talent show?

13 What is different about this year's film festival?
A They do a variety of activties.
B They may cancel their appearance.
C Their performance last year was disappointing.
A every week in July.
B more than once in July.
C only in July.
A the weather is likely to be bad.
B not enough people bought tickets.
C the actors have to be somewhere else.
A on a boat.
B on a bridge.
C in a tent.
A They must be under eighteen.
B Their performance must last for less than ten minutes.
C They must have applied to take part.




\section{Part 3}

\section{Questions 14-19}

You will hear somebody welcoming a group of international students to a college. For each question, fill in the missing information in the numbered space.

\section{Highdown College}

\section{Accommodation}

Office at the college (14)

Opening hours - term time:

Monday - Friday

9 a.m. to 4 p.m.

(Holidays: Monday and (15)

Emergency No. (16)

\section{College facilities}

Learning Resource Centre - over 50,000 library books 50 (17) with internet facilities

Snacks (including sandwiches and (18) ...) - in The Hungry Café on the first floor

Hot meals - in The Food Hall on the ground floor next to the (19)

Pub lunch - in the Students' Bar

\section{Tip}

You will hear the exact word you need for the answer, but the words or sentence you hear around it may not be exactly the same as on the question paper.

mornings only)

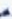




\section{Paper 3 Speaking (10-12 minutes)}

\section{Part 1 Personal information (2-3 minutes)}

Answer these questions:

What's your name?

What's your surname? How do you spell it?

Where do you live?

Do you work or are you a student?

Do you enjoy studying English?

Do you think that English will be useful to you in the future?

What do you enjoy doing in your free time?

\section{Part 2 Simulated situation (2-3 minutes)}

You are spending the evening with a friend who you have not seen for a long time.

Look at the picture on page 75.

Talk about what you could do and decide what would be the most suitable.

\section{Part 3 Responding to a photograph (3 minutes)}

Candidate A: look at Photo 1 on page 95, show it to Candidate B and talk about it.

Candidate B: look at Photo 2 on page 96, show it to Candidate A and talk about it.

\section{Part 4 General conversation based on the photographs (3 minutes)}

Talk to each other about your favourite season.

Talk about what you enjoy doing at different times of year.
Tip

You may have to give numbers, e.g. your telephone number. Make sure you can say them properly, and be careful with numbers you know are difficult.
Tip

Try to say something about as many of the pictures as you can but don't worry if you don't have enough time.

Tip

If you aren't sure about things in the photo, use expressions like "I think'. 'It looks like', 'It might/could be', etc.

Tip

It doesn't matter if you agree or disagree with what your partner says. It is a discussion, not an argumentl 


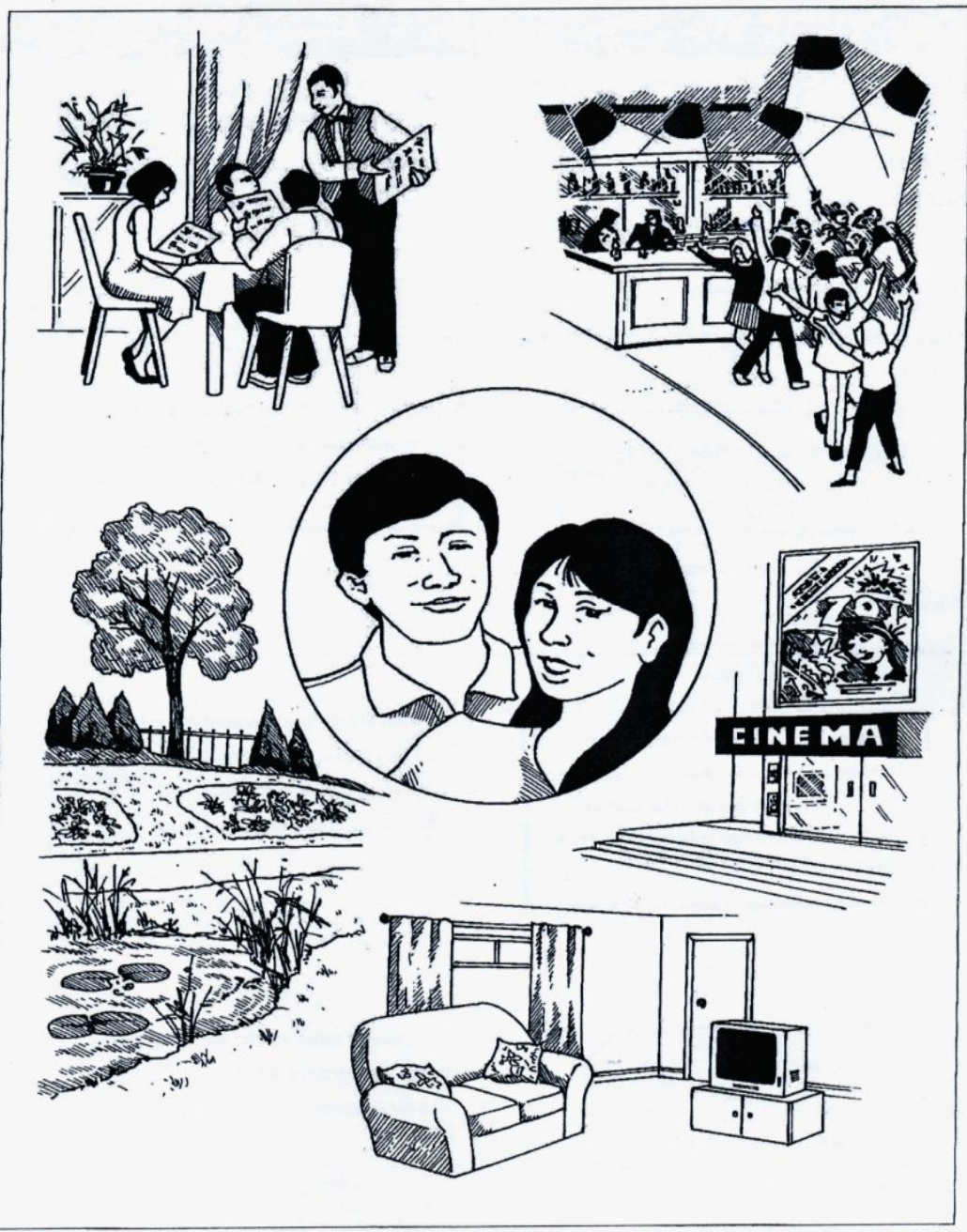

